British Journal of Nutrition (2022), 128, 1955-1965

doi:10.1017/S0007114521004906

(C) The Author(s), 2021. Published by Cambridge University Press on behalf of The Nutrition Society. This is an Open Access article, distributed under the terms of the Creative Commons Attribution licence (https://creativecommons.org/licenses/by/4.0/), which permits unrestricted re-use, distribution, and reproduction in any medium, provided the original work is properly cited.

\title{
Ingestion of an ample amount of meat substitute based on a lysine-enriched, plant-based protein blend stimulates postprandial muscle protein synthesis to a similar extent as an isonitrogenous amount of chicken in healthy, young men
}

Imre W.K. Kouw ${ }^{1,2}$, Philippe J.M. Pinckaers ${ }^{1,2}$, Cindy Le Bourgot ${ }^{3}$, Janneau M.X. van Kranenburg ${ }^{1,2}$, Antoine H. Zorenc ${ }^{1}$, Lisette C.P.G.M. de Groot ${ }^{2,4}$, Lex Verdijk ${ }^{1,2}$, Tim Snijders ${ }^{1,2}$ and Luc J.C. van Loon ${ }^{1,2 *}$ ${ }^{1}$ Department of Human Biology, NUTRIM School for Nutrition and Translational Research in Metabolism, Maastricht University Medical Centre+, Maastricht, The Netherlands

${ }^{2}$ TiFN, Wageningen, The Netherlands

${ }^{3}$ Research and Development, Tereos, Moussy-Le-Vieux, France

${ }^{4}$ Division of Human Nutrition \& Health, Department of Agrotechnology and Food Sciences, Wageningen University \& Research, Wageningen, The Netherlands

(Submitted 8 February 2021 - Final revision received 25 October 2021 - Accepted 24 November 2021 - First published online 9 December 2021)

\section{Abstract}

Plant-based proteins are considered to be less effective in their capacity to stimulate muscle protein synthesis when compared with animal-based protein sources, likely due to differences in amino acid contents. We compared the postprandial muscle protein synthetic response following the ingestion of a lysine-enriched plant-based protein product with an isonitrogenous amount of chicken. Twenty-four men (age $24 \pm 5$ years; BMI $22.9 \pm 2.6 \mathrm{~kg} \cdot \mathrm{m}^{-2}$ ) participated in this parallel, double-blind, randomised controlled trial and consumed $40 \mathrm{~g}$ of protein as a lysine-enriched wheat and chickpea protein product (Plant, $n 12)$ or chicken breast fillet (Chicken, $n 12)$. Primed, continuous intravenous $\mathrm{L}-\left(\right.$ ring- $\left.{ }^{13} \mathrm{C}_{6}\right)-$ phenylalanine infusions were applied while repeated blood and muscle samples were collected over a 5 -h postprandial period to assess plasma amino acid responses, muscle protein synthesis rates and muscle anabolic signalling responses. Postprandial plasma leucine and essential amino acid concentrations were higher following Chicken $(P<0 \cdot 001)$, while plasma lysine concentrations were higher throughout in Plant $(P<0 \cdot 001)$. Total plasma amino acid concentrations did not differ between interventions $(P=0 \cdot 181)$. Ingestion of both Plant and Chicken increased muscle protein synthesis rates from post-absorptive: $0 \cdot 031 \pm 0 \cdot 011$ and $0 \cdot 031 \pm 0 \cdot 013$ to postprandial: $0 \cdot 046 \pm 0 \cdot 010$ and $0 \cdot 055 \pm 0 \cdot 015 \% \mathrm{~h}^{-1}$, respectively ( $P$-time $<0.001$ ), with no differences between Plant and Chicken (time x treatment $P=0.068$ ). Ingestion of $40 \mathrm{~g}$ of protein in the form of a lysineenriched plant-based protein product increases muscle protein synthesis rates to a similar extent as an isonitrogenous amount of chicken in healthy, young men. Plant-based protein products sold as meat replacers may be as effective as animal-based protein sources to stimulate postprandial muscle protein synthesis rates in healthy, young individuals.

Key words: Muscle protein synthesis: Plant-based proteins: Chicken: Meat substitute: Protein blends

Skeletal muscle mass maintenance is regulated by the balance between muscle protein synthesis and breakdown rates. The stimulation of muscle protein synthesis by food intake (i.e. dietary protein ingestion and subsequent aminoacidemia) and physical activity (i.e. resistance type exercise) are key factors responsible for the maintenance of skeletal muscle mass. The amplitude and duration of the muscle protein synthetic response to protein ingestion is modulated by the amount ${ }^{(1-3)}$, source $^{(4-7)}$ and type of protein ${ }^{(4,8)}$ that is consumed, as well as the matrix in which it is embedded ${ }^{(9-11)}$. In addition, the essential amino acid
(EAA) composition of the protein that is consumed, and the leucine content in particular, plays a key role in the postprandial stimulation of muscle protein synthesis ${ }^{(12)}$.

The consumption of plant-based protein sources and the use of plant-based protein isolates and concentrates in food formulations and products are increasing worldwide, which is mainly due to the increasing awareness regarding food sustainability and the lower production cost of plant-based proteins ${ }^{(13)}$. However, based on their digestibility and/or amino acid composition, plant-based protein sources are generally considered of a

Abbreviations: EAA, essential amino acid; FSR, fractional synthesis rate; MPE, mole percent excess.

* Corresponding author: Luc J. C. van Loon, email 1.vanloon@maastrichtuniversity.nl 
lesser quality when compared with animal-based proteins ${ }^{(14-16)}$. In accordance, the postprandial muscle protein synthetic response to the ingestion of plant-based proteins has been shown to be lower when compared with the ingestion of an isonitrogenous amount of animal-based protein ${ }^{(6,7,17,18)}$. The lesser anabolic properties of plant-based proteins have been attributed to the lower EAA content and the shortage of specific amino acids such as leucine, lysine and/or methionine ${ }^{(14,15,19,20)}$. Since all amino acids are required as precursors for muscle protein synthesis, the lack of one or more amino acids may compromise the postprandial muscle protein synthetic response. Though there are only a few studies that have assessed muscle protein synthesis rates following the ingestion of plantbased proteins; a lower muscle protein synthetic response to the ingestion of $\operatorname{soy}^{(7,17,18)}$ and wheat ${ }^{(6)}$ has been consistently reported when compared with the ingestion of animal-based protein sources such as milk or beef.

To compensate for the proposed lesser anabolic potential of plant-based proteins, more of the plant-based protein could be consumed to induce a similar postprandial increase in muscle protein synthesis rates when compared with a high-quality animal-based protein source ${ }^{(6)}$. Although effective, increasing the dose of plant-based proteins to compensate for their lower anabolic properties may not always be practical or feasible. Other strategies to increase the anabolic potential of a plantbased protein source may be to fortify with specific amino acids or the use of specific blends of various plant-based proteins that have opposing differences in their specific shortages of one or more amino acids. Recent innovations in food processing and the selection of specific plant-based protein blends may optimise the quality of a plant-based protein meal and, as such, increase the postprandial muscle protein synthetic response ${ }^{(21-23)}$. As a result, there is an extensive range of plant-based protein products (as alternatives to meat consumption) available on the market; their capacity to stimulate muscle protein synthesis, however, has not yet been assessed. We aimed to compare the muscle protein synthetic response following the ingestion of an ample amount of a plant-based, whole-food protein source (a meat alternative) with an equivalent amount of an animal-based protein source. We hypothesised that ingestion of a lysineenriched, plant-based protein product can increase muscle protein synthesis rates in healthy individuals. Furthermore, we hypothesised that the postprandial muscle protein synthetic response following the ingestion of an ample amount of such a plant-based meat alternative would not differ from the ingestion of an isonitrogenous amount of chicken. To test our hypothesis, we assessed basal and postprandial muscle protein synthesis rates using contemporary stable isotope methodology following ingestion of $40 \mathrm{~g}$ of protein provided via a lysine-enriched, wheat and chickpea protein-based product or an isonitrogenous amount of chicken in twenty-four healthy, young men.

\section{Methods \\ Participants}

Twenty-four healthy, young, recreationally active men (aged 18-35 years, BMI $18-27.5 \mathrm{~kg} \mathrm{~m}^{-2}$ ) volunteered to participate in this parallel, double-blind, randomised controlled trial (recreationally active was defined as engaging in sports or structured exercise $\leq 3 \mathrm{~d}$ /week and not participating in any structured resistance type exercise programme). Participants' characteristics are presented in Table 1 . The flow chart of participant enrolment is shown in Supplemental Fig. 1. This study was registered at the Netherlands Trial Register (NTR6380) and was conducted between June 2017 and October 2017 at Maastricht University Medical Centre+, Maastricht, the Netherlands. All participants were informed on the purpose of the study, the experimental procedures and possible risks before providing informed written consent to participate. The procedures followed were in accordance with the ethical standards of the medical ethics committee of Maastricht University Medical Centre+ on human experimentation and in accordance with the Helsinki Declaration of 1975 as revised in October 2013. The study was independently monitored by the Clinical Trial Centre Maastricht.

\section{Pre-testing}

Participants underwent an initial screening session to assess height, weight, blood pressure and body composition (by dual-energy X-ray absorptiometry; Hologic Inc., DXA; Discovery A, QDR series). Whole-body and appendicular (sum of lean mass of both arms and legs) lean mass and body fat was determined using the software package Apex (en-CORE 2005, version 4.0.2. Hologic) and reference values

Table 1. Subjects' characteristics

\begin{tabular}{|c|c|c|c|c|}
\hline & \multicolumn{2}{|c|}{ Plant $(n=12)$} & \multicolumn{2}{|c|}{ Chicken $(n=12)$} \\
\hline & Mean & SD & Mean & SD \\
\hline Age (year) & 24 & 4 & 24 & 5 \\
\hline Weight (kg) & $77 \cdot 6$ & 14.5 & 71.3 & 7.4 \\
\hline $\mathrm{BMI}\left(\mathrm{kg} \cdot \mathrm{m}^{-2}\right)$ & 23.5 & 2.9 & $22 \cdot 2$ & $2 \cdot 1$ \\
\hline Diastolic blood pressure $\left(\mathrm{mm} \mathrm{Hg}^{-1}\right)$ & 71 & 14 & 67 & 6 \\
\hline Systolic blood pressure $\left(\mathrm{mm} \mathrm{Hg}^{-1}\right)$ & 128 & 13 & 121 & 10 \\
\hline Lean body mass $(\mathrm{kg})$ & 60.7 & $12 \cdot 2$ & 54.2 & 5.4 \\
\hline Lean body mass (\%) & $78 \cdot 0$ & $2 \cdot 9$ & $76 \cdot 2$ & $5 \cdot 3$ \\
\hline Fat mass $(\mathrm{kg})$ & $15 \cdot 1$ & 3.3 & $15 \cdot 3$ & 4.9 \\
\hline Fat mass $(\%)$ & $19 \cdot 6$ & 3.3 & 21.1 & 5.6 \\
\hline Appendicular lean mass $(\mathrm{kg})^{*}$ & $28 \cdot 3$ & 6.3 & $25 \cdot 1$ & $3 \cdot 2$ \\
\hline Appendicular lean mass (\%) & $36 \cdot 2$ & $2 \cdot 0$ & 35.3 & $3 \cdot 2$ \\
\hline
\end{tabular}

*Appendicular lean mass was calculated by the sum of lean mass of both arms and legs. Data were analysed by unpaired Student's $t$ test, $P<0.05$. No significant differences were observed between groups. 
from the National Health and Nutrition Examination Survey (NHANES) population-based dataset ${ }^{(24)}$. Participants were deemed healthy based on their responses to a medical questionnaire and screening results. All participants were instructed to refrain from strenuous physical activity and alcohol consumption for $3 \mathrm{~d}$ before the experimental trial. On the evening before the experimental trial, all participants consumed a pre-packaged standardised meal (Maaltijdpannetje, Aviko) containing 55\% energy as carbohydrate, $30 \%$ energy as fat and $15 \%$ energy as protein before 20:00, after which they remained fasted.

\section{Dietary intervention}

Participants were randomly assigned to consume $40 \mathrm{~g}$ of protein in the form of either $230 \mathrm{~g}$ of a baked lysine-enriched, plantbased meat substitute (Plant) or $174 \mathrm{~g}$ of baked chicken breast (Chicken). We selected an existing plant-based meat alternative (Tereos, France) typically available on the market. As plantbased meat substitutes usually provide more fat and/or carbohydrate relative to the amount of protein when compared with animal-based products, we compared products based on the same amount of protein provided. The lysine-enriched, plantbased protein product was composed of a blend of wheat and chickpea flour (60/40 ratio) and supplemented with 5\% free lysine/100 g (L-lysine monohydrochloride), up to about $200 \%$ of the recommended levels of the $\mathrm{FAO} / \mathrm{WHO}$, in order to fortify the lysine content in the product that was naturally lacking in lysine and below the recommended intake levels according to the FAO standards. The product was produced by extrusion of the protein blend into small shredded, diced pieces at temperatures $<100^{\circ} \mathrm{C}$ followed by cooking at about $135^{\circ} \mathrm{C}$. A staff member not involved in the study generated random assignment of the treatments and participant codes using a computerised list randomiser (www.random.org), and participants were sequentially allocated to a treatment according to the random assignment list that was stored in a closed cabinet. Meals were prepared by a staff member not involved in the study, served on an identical white plate and provided with the randomisation code, making them blinded to both participants and researchers. Both meals were presented in identical form and appearance (small, diced pieces) and baked for $9 \mathrm{~min}$ in $7 \mathrm{~g}$ of olive oil (15\% extra virgin olive oil) in a frying pan. No additional flavouring was added. Qualitative measurements on palatability were taken directly after consumption of the meals by providing participants with visual analogue scales and are presented in Online Supplemental Material. Macronutrient breakdown and amino acid composition are shown in Tables 2 and 3, and the plasma appearance of specific amino acids following ingestion of Plant and Chicken are provided in the Online Supplemental Material. The amino acid content of both interventions was determined as previously described ${ }^{(15)}$ and described in detail in Online Supplemental Material. In short, approximately $5 \mathrm{mg}$ of freezedried Plant or Chicken was hydrolysed in $3 \mathrm{ml}$ of $6 \mathrm{M} \mathrm{HCl}$ for $12 \mathrm{~h}$ at $110^{\circ} \mathrm{C}$. After hydrolysis, $\mathrm{HCl}$ was evaporated under nitrogen stream, while heated to $120^{\circ} \mathrm{C}$ and the dried amino acids were reconstituted in $5 \mathrm{ml}$ of $0.1 \mathrm{M} \mathrm{HCl}$. Amino acids were measured by using ultra-performance liquid chromatographyMS (ACQUITY UPLC H-Class with QDa; Waters).
Table 2. Macronutrient composition of protein meals

\begin{tabular}{lccccc}
\hline & \multicolumn{2}{c}{$\begin{array}{c}\text { Plant } \\
(n=12)\end{array}$} & & \multicolumn{2}{c}{$\begin{array}{c}\text { Chicken } \\
(n=12)\end{array}$} \\
\cline { 2 - 3 } \cline { 5 - 6 } \cline { 5 - 6 } & $\begin{array}{c}\text { per } \\
100 \mathrm{~g}\end{array}$ & $\begin{array}{c}\text { per serving size } \\
(230 \mathrm{~g})\end{array}$ & & $\begin{array}{c}\text { per } \\
100 \mathrm{~g}\end{array}$ & $\begin{array}{c}\text { per serving size } \\
(174 \mathrm{~g})\end{array}$ \\
\hline Energy content (kJ) & 559 & 1286 & & 461 & 802 \\
Protein (g) & 17.4 & 39.9 & & 23.0 & 39.9 \\
Carbohydrates $(\mathrm{g})$ & 11.1 & 18.2 & & 0 & 0 \\
Fat $(\mathrm{g})$ & 6.5 & 10.7 & & 1.8 & 3.1 \\
\hline
\end{tabular}

Table 3. Amino acid composition of raw product

\begin{tabular}{|c|c|c|c|c|}
\hline & $\begin{array}{c}\text { Plant } \\
(n=12)\end{array}$ & $\begin{array}{l}\text { Chicken } \\
(n=12)\end{array}$ & $\begin{array}{c}\text { Plant } \\
(n=12)\end{array}$ & $\begin{array}{l}\text { Chicken } \\
(n=12)\end{array}$ \\
\hline & \multicolumn{2}{|c|}{$\mathrm{g}$ per $100 \mathrm{~g}$ protein } & \multicolumn{2}{|c|}{ g per serving size } \\
\hline Alanine & $2 \cdot 50$ & $4 \cdot 76$ & 1.00 & 1.90 \\
\hline Arginine & 3.19 & $4 \cdot 19$ & $1 \cdot 27$ & 1.68 \\
\hline Aspartic acid & 3.07 & 7.02 & $1 \cdot 23$ & $2 \cdot 81$ \\
\hline Asparagine & $N D^{*}$ & $N D^{*}$ & $\mathrm{ND}^{*}$ & $N D^{*}$ \\
\hline Cysteine & 0.58 & 0.14 & 0.23 & 0.06 \\
\hline Glutamic acid & $20 \cdot 28$ & $9 \cdot 08$ & $8 \cdot 11$ & 3.63 \\
\hline Glycine & $2 \cdot 80$ & 3.25 & $1 \cdot 12$ & 1.30 \\
\hline Histidine & 1.52 & $2 \cdot 31$ & 0.61 & 0.93 \\
\hline Isoleucine & $2 \cdot 10$ & 2.33 & 0.84 & 0.93 \\
\hline Leucine & $5 \cdot 78$ & 6.08 & $2 \cdot 31$ & 2.43 \\
\hline Lysine & 8.68 & $6 \cdot 54$ & 3.47 & $2 \cdot 61$ \\
\hline Methionine & 0.87 & $2 \cdot 27$ & 0.35 & 0.91 \\
\hline Ornithine & ND* & $\mathrm{ND}^{*}$ & $N^{*}$ & $N D^{*}$ \\
\hline Phenylalanine & $4 \cdot 82$ & 2.94 & 1.93 & $1 \cdot 17$ \\
\hline Proline & $10 \cdot 11$ & $2 \cdot 56$ & 4.04 & 1.02 \\
\hline Serine & $4 \cdot 84$ & 2.93 & 1.93 & 1.17 \\
\hline Threonine & $2 \cdot 27$ & 3.22 & 0.91 & 1.29 \\
\hline Tyrosine & 1.25 & 1.20 & 0.50 & 0.48 \\
\hline Valine & $2 \cdot 35$ & 2.42 & 0.94 & 0.97 \\
\hline TAA & 77.02 & 63.24 & $30 \cdot 81$ & $25 \cdot 30$ \\
\hline EAA & 28.40 & 28.11 & 11.36 & 11.24 \\
\hline BCAA & $10 \cdot 23$ & $10 \cdot 82$ & 4.09 & $4 \cdot 33$ \\
\hline NEAA & $48 \cdot 61$ & $35 \cdot 13$ & $19 \cdot 45$ & 14.05 \\
\hline
\end{tabular}

TAA, sum of total amino acids; EAA, essential amino acids; BCAA, branched-chain amino acids; NEAA, non-essential amino acids.

${ }^{*}$ Not detectable.

\section{Experimental protocol}

At 07:30, participants arrived at the laboratory after an overnight fast. A peripheral intravenous catheter was inserted into an antecubital vein for stable isotope amino acid infusion, and a second catheter was inserted into a dorsal hand vein on the contralateral arm for arterialised blood sampling (the hand was placed in a hot box $\left(60^{\circ} \mathrm{C}\right)$ for $10 \mathrm{~min}$ before sample collection (24)). After taking a baseline blood sample ( $t=-180 \mathrm{~min})$, the plasma phenylalanine pool was primed with a single dose of L-(ring- $\left.{ }^{13} \mathrm{C}_{6}\right)$-phenylalanine $\left(2 \cdot 25 \mu \mathrm{mol} \mathrm{kg}^{-1}\right)$, and subsequently, a continuous intravenous infusion of $\mathrm{L}-\left(\right.$ ring- $\left.-{ }^{13} \mathrm{C}_{6}\right)$-phenylalanine $\left(0.05 \mu \mathrm{mol} \mathrm{kg}^{-1} \mathrm{~min}^{-1}\right)$ was initiated $(t=-180 \mathrm{~min})$ with use of a calibrated IVAC 598 pump. While resting in a supine position, blood samples were taken at $t=-90,-60$ and -30 min relative to meal ingestion. At $t=0 \mathrm{~min}$, a blood sample and a muscle biopsy sample from the $M$. vastus lateralis of a randomly 
selected leg were collected to assess post-absorptive muscle protein synthesis. Subsequently, participants received a protein meal corresponding to their randomly assigned treatment (Plant $(n=12)$ or Chicken $(n=12))$. All subjects ingested a $150 \mathrm{ml}$ water beverage (and were instructed to consume this consistently throughout their meal) with $3.85 \%$ free, crystalline L-(ring- ${ }^{13} \mathrm{C}_{6}$ )-phenylalanine to minimise dilution of the steadystate plasma L-(ring- ${ }^{13} \mathrm{C}_{6}$ )-phenylalanine precursor pool implemented by the constant infusion. Arterialised blood samples were then collected at $t=15,30,60,90,120,150,180,240$ and $300 \mathrm{~min}$. A second and third muscle biopsy sample were collected at $t=120$ and $t=300$ min to determine postprandial muscle protein synthesis rates from $t=0-120,120-300$ and 0-300 min. Blood samples were collected into EDTA-containing tubes and centrifuged at $1000 \mathrm{~g}$ for $15 \mathrm{~min}$ at $4^{\circ} \mathrm{C}$. Aliquots of plasma were frozen in liquid nitrogen and stored at $-80^{\circ} \mathrm{C}$. Muscle samples were collected with the use of a $5-\mathrm{mm}$ Bergström needle custom-adapted for manual suction ${ }^{(25)}$. Samples were obtained from separate incisions from the middle region of the $M$. vastus lateralis, about $15 \mathrm{~cm}$ above the patella and about $3 \mathrm{~cm}$ below entry through the fascia, under $1 \%$ xylocaine local anaesthesia with adrenaline (1:100·000). Muscle samples were freed from any visible non-muscle material, immediately frozen in liquid nitrogen and stored at $-80^{\circ} \mathrm{C}$ until further processing.

\section{Plasma and muscle analyses}

Details of analysis related to the determination in plasma (glucose, insulin, and amino acid concentrations and plasma $\mathrm{L}$-(ring- ${ }^{13} \mathrm{C}_{6}$ )-phenylalanine enrichments) as well as muscle (mixed muscle protein-bound $\mathrm{L}$-(ring- ${ }^{13} \mathrm{C}_{6}$ )-phenylalanine enrichments and protein signalling) are presented in the Online Supplemental Material.

\section{Calculations}

The present study involved the infusion of $\mathrm{L}-\left(\right.$ ring- $\left.{ }^{13} \mathrm{C}_{6}\right)$-phenylalanine combined with muscle biopsy and arterialised venous blood sampling to determine the fractional synthesis rates (FSR) of mixed muscle proteins in the basal and postprandial state and were calculated by using the standard precursorproduct equation:

$$
F S R=\frac{\Delta E p}{E_{\text {precursor }} \cdot t} \cdot 100 \%
$$

where $\triangle E P$ is the increment in muscle protein-bound L-(ring- ${ }^{13} \mathrm{C}_{6}$ )-phenylalanine enrichment after an incorporation period (in mole percent excess, MPE), $E_{\text {precursor }}$ is the weighted average plasma $\mathrm{L}-\left(\right.$ ring $\left.-{ }^{13} \mathrm{C}_{6}\right)$-phenylalanine enrichment during the tracer incorporation period (MPE) and $t$ is the incorporation time (h). Weighted mean plasma enrichments were calculated by taking the measured enrichments between consecutive time points and correcting for the time between these sampling time points. For basal FSR, mixed plasma protein samples at $t=-180$ min and muscle biopsy samples at $t=0$ min were used (single biopsy approach); ${ }^{(26)}$ for postprandial FSR, muscle biopsy samples at $t=0,120$ and 300 min were used.

\section{Statistical analysis}

All data are expressed as mean and standard deviation. Subjects' characteristics and baseline data (including basal FSR and anabolic signalling) were analysed using unpaired, two-tailed Student's $t$ tests. The primary outcome of the study was mixed muscle FSR (change from the basal to postprandial period), secondary outcomes included plasma glucose, insulin, amino acid concentrations (changes over time, total AUC and time to peak) and anabolic signalling responses (changes over time). Two-factor repeated-measures ANOVA with time as withinsubject factor and intervention as between-treatment factor was used to compare differences over time in plasma glucose, insulin, amino acid concentrations and enrichments, anabolic signalling, and FSR (basal to the 0-120 min and 120-300 min postprandial period, and basal to the cumulative $0-300$ min postprandial period). In case of significant time $\times$ treatment interactions, separate analyses were performed to determine time effects for each treatment (one-factor repeated-measures ANOVA with Bonferroni post hoc tests to identify time differences) and between-treatment effects for each time point (unpaired, two-tailed Student's $t$ test). Peak values, time to peak and AUC were calculated for plasma time curves, and differences were determined using unpaired, two-tailed Student's $t$ tests. Based on previous studies ${ }^{(6)}$, a sample size of twelve subjects per intervention including a $10 \%$ dropout rate was calculated, using a unpaired, two-sided statistical test $(P<0 \cdot 05,95 \%$ power, effect size 1.8), to detect differences in FSR between treatments. For all analyses, statistical significance was set at $P<0 \cdot 05$. All calculations were performed using SPSS (IBM Statistics, version 25.0, IBM Corp.).

\section{Results}

\section{Plasma glucose and insulin}

Plasma glucose and insulin concentrations are shown in Fig. 1. Following the ingestion of the 40-g protein meal, plasma glucose concentrations (Fig. 1(a)) increased to a greater extent in Plant when compared with Chicken (time $\mathrm{x}$ treatment $P<0 \cdot 001$ ). Plasma glucose concentrations reached peak values at $30 \pm 0 \mathrm{~min}$ in Plant $\left(6 \cdot 1 \pm 0 \cdot 2 \mathrm{mmol} \mathrm{l^{-1 }}\right)$ and were higher when compared with peak values in Chicken $\left(5.4 \pm 0.4 \mathrm{mmol}^{-1}\right.$ at $140 \pm 59 \mathrm{~min} ; P<0.001)$. Following protein ingestion, plasma insulin concentrations (Fig. 1(b)) increased to a greater extent after Plant ingestion when compared with Chicken (time $\mathrm{x}$ treatment $P<0.001)$. Plasma insulin concentrations in Plant peaked at $38 \pm 19 \mathrm{~min}$, reaching concentrations of $205 \pm 73$ pmol $1^{-1}$, and were higher when compared with Chicken, reaching peak values of $111 \pm 39 \mathrm{pmol}^{-1}$ at $78 \pm 37 \mathrm{~min}$ $(P<0.05)$. Plasma insulin responses (AUC) were higher at $0-2 \mathrm{~h}(P=0.003)$ and $0-5 \mathrm{~h}(P=0.031)$ in Plant when compared with Chicken.

\section{Plasma amino acid concentrations}

Plasma amino acid concentrations are shown in Figs. 2 and 3. Plasma leucine concentrations (Fig. 2(a)) increased following meal ingestion, but to a greater extent in Chicken when 
(a)

compared with Plant (time $\mathrm{x}$ treatment $P<0 \cdot 001$ ). Plasma leucine concentrations were higher in Chicken (peak values $290 \pm 28 \mu \mathrm{mol} \mathrm{l}^{-1}$ ) when compared with Plant (peak values $\left.200 \pm 34 \mu \mathrm{mol} \mathrm{l}^{-1}\right)$ from $t=60-240 \mathrm{~min}(P<0 \cdot 05)$. The AUC of plasma leucine concentrations was higher in Chicken in the $0-2 \mathrm{~h}$ and $0-5 \mathrm{~h}$ postprandial period when compared with Plant (both, $P<0.001$ ). Plasma lysine concentrations (Fig. 2(b)) rapidly increased following Plant ingestion (time $\mathrm{x}$ treatment $P<0 \cdot 001$ ), reaching peak concentrations of $517 \pm 77 \mu \mathrm{mol} \mathrm{l}^{-1}$, and were higher when compared with Chicken (peak values $324 \pm 28 \mu \mathrm{mol} \mathrm{l^{-1 }}$ ) throughout the postprandial period from $t=15-90 \mathrm{~min}(P<0 \cdot 001)$. Plasma methionine concentrations (Fig. 2(c)) increased to a greater extent following ingestion of Chicken when compared with Plant (time $\mathrm{x}$ treatment $P<0.001)$ and remained elevated in Chicken from $30-300 \mathrm{~min}$ following protein ingestion $(P<0 \cdot 05)$.

The sum of specific subgroups of plasma amino acids is shown in Fig. 3. Plasma EAA (Fig. 3(a)) increased following protein ingestion in both interventions (time $\mathrm{x}$ treatment $P<0.001$; time effect, both $P<0.001)$ and were higher following Plant when compared with Chicken from $t=0-45 \mathrm{~min}$ though conversely from $t=90-240 \min (P<0.05)$. The AUC of
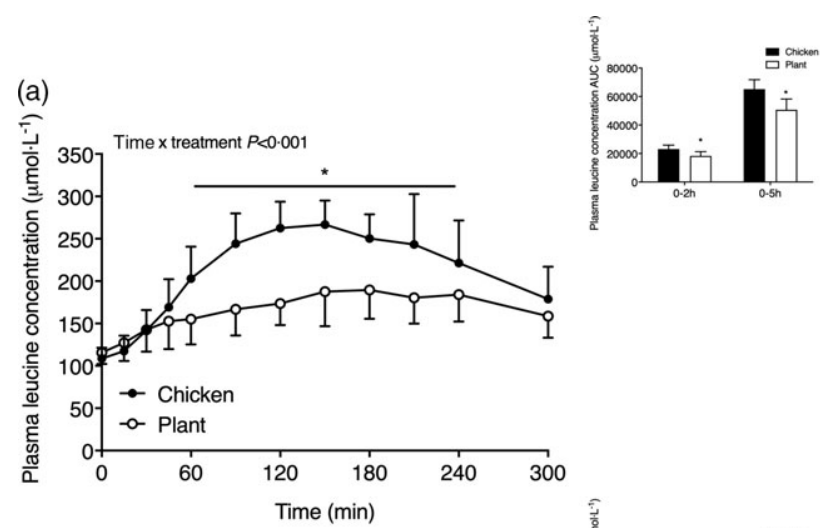

(b)
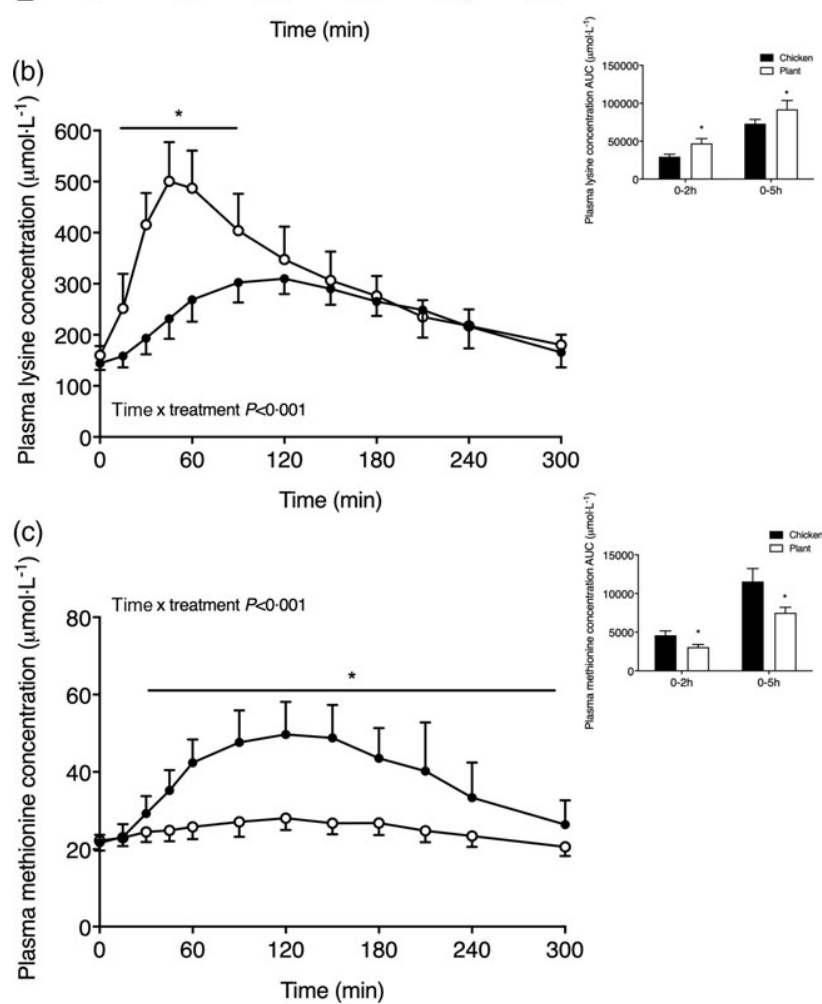

Fig. 2. Plasma leucine (a), lysine (b) and methionine (c) concentrations in twenty-four healthy, young men following the ingestion of $40 \mathrm{~g}$ of protein of either a lysine-enriched, wheat and chickpea protein product (Plant; $n=12$ ) or chicken breast fillet (Chicken; $n=12$ ). Values represent means and standard deviation. Insets represent AUC. Data were analysed by repeated-measures (time $\times$ treatment) ANOVA. Bonferroni post hoc test was used to locate differences over time. (a) Time $\times$ treatment interaction, $P<0.001$. (b) Time $\times$ treatment interaction, $P<0.001$. (c) Time $\times$ treatment interaction, $P<0.001$. ${ }^{*} \mathrm{~A}$ significant difference between treatments, $P<0.05$.

EAA did not differ during the $0-2 \mathrm{~h}$ postprandial period $(P=0.438)$ but was lower in Plant when compared with Chicken over the 5 -h postprandial period $(P<0 \cdot 01)$. Plasma branched-chain amino acids (Fig. 3(b)) were higher in Chicken when compared with Plant from 60 min after protein meal ingestion and throughout the remainder of the postprandial period time $\mathrm{x}$ treatment $\mathrm{P}<0.001$, post hoc all, $P<0.05$ ). The AUC of the branched-chain amino acids was higher in Chicken when compared with Plant in both the $0-2 \mathrm{~h}$ and $0-5$ h phase $(P<0.05)$. Plasma non-essential amino acids (Fig. $3(\mathrm{c}))$ differed between treatments (time $\mathrm{x}$ treatment $P<0.05$ ) 

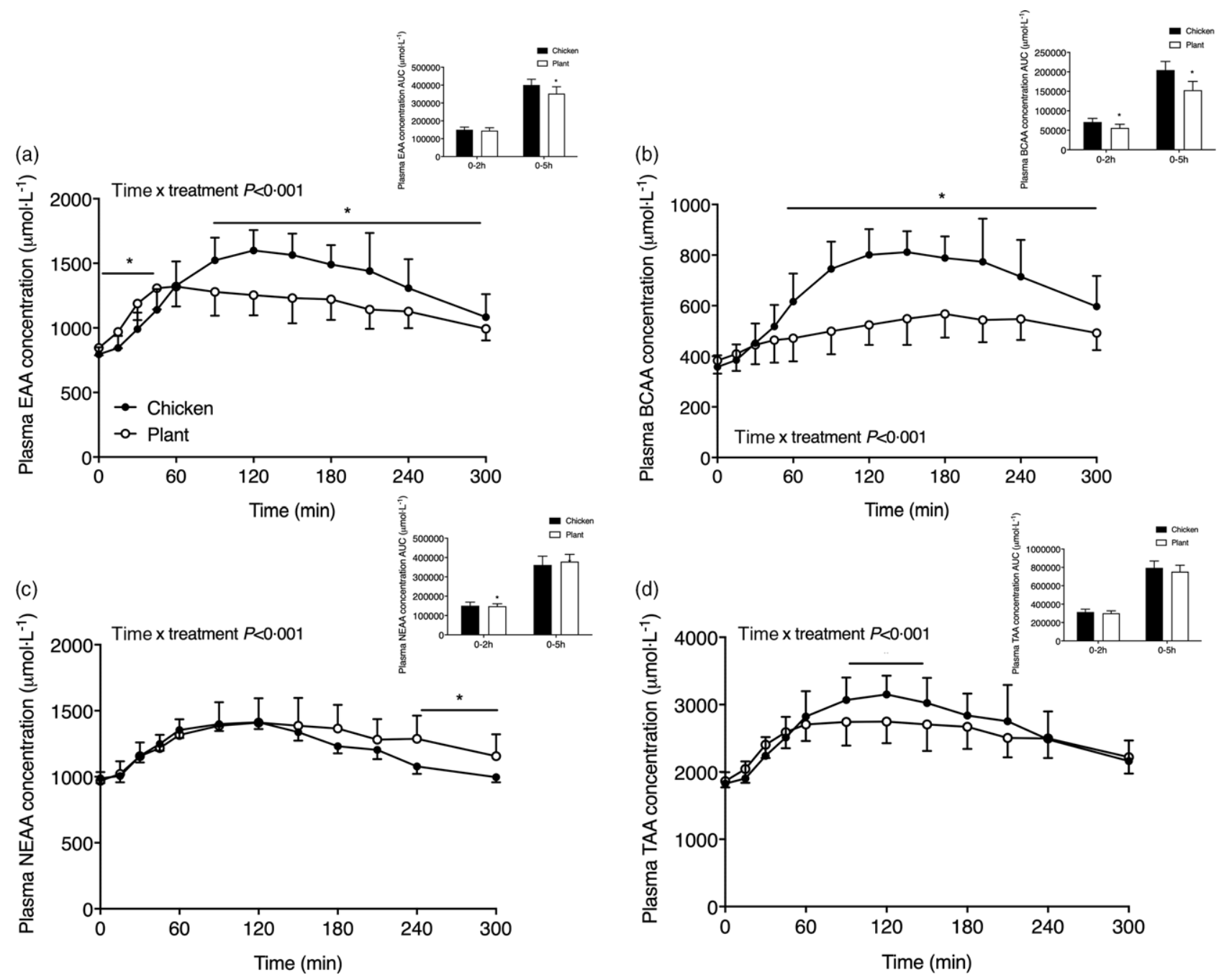

Fig. 3. Sum of plasma essential amino acids (a), branched-chain amino acids (b), non-essential amino acids (c) and the sum of all amino acids (d) in twenty-four healthy, young men following the ingestion of $40 \mathrm{~g}$ of protein of either a lysine-enriched, wheat and chickpea protein product (Plant; $n=12$ ) or chicken breast fillet (Chicken; $n=12$ ). Values represent means and standard deviation. Insets represent AUC. Data were analysed by repeated-measures (time $\times$ treatment) ANOVA. Bonferroni post hoc test was used to locate differences over time. (a) Time $\times$ treatment interaction, $P<0.001$. (b) Time $\times$ treatment interaction, $P<0.001$. (c) Time $\times$ treatment interaction, $P<0.001$. (d) Time $\times$ treatment interaction, $P<0.001$. ${ }^{*}$ A significant difference between treatments, $P<0.05$. EAA, essential amino acids; BCAA, branched-chain amino acids; NEAA, non-essential amino acids; TAA, sum of all amino acids.

and were higher in Plant when compared with Chicken from $t=240-300$ min following meal ingestion (all, $P<0 \cdot 05$ ). The sum of all amino acids Fig. 3(d)) differed between interventions (time $\mathrm{x}$ treatment $P<0.05$ ) and were higher in Chicken when compared with Plant from $t=90-150$ min following meal ingestion (all, $P<0.05$ ). The AUC of non-essential amino acids and sum of all amino acids did not differ between interventions (both, $P>0.05$ ). Individual plasma amino acid concentrations of alanine, arginine, asparagine, aspartic acid, $\beta$-alanine, cystine, glutamic acid, glycine, histidine, isoleucine, ornithine, phenylalanine, proline, serine, threonine, tryptophan, tyrosine and valine are presented in Supplemental Figs. 2 and 3.

\section{Muscle protein synthesis rates}

Prior to ingestion of the meal, plasma L-(ring- $\left.{ }^{13} \mathrm{C}_{6}\right)$-phenylalanine weighted mean enrichments averaged 6.6 $\pm 0.6 \mathrm{MPE}$ in
Chicken and 6.7 $\pm 0.4 \mathrm{MPE}$ in Plant with no differences between interventions $(P=0.940 ;$ Supplemental Fig. 4). Plasma L-(ring- ${ }^{13} \mathrm{C}_{6}$ )-phenylalanine enrichments increased directly following the ingestion of the protein meal (main time effect, $P<0.001$ ) but returned rapidly to baseline steadystate levels. Postprandial plasma $\mathrm{L}_{\mathrm{L}}\left(\mathrm{ring}_{-}{ }^{13} \mathrm{C}_{6}\right)$-phenylalanine weighted means averaged $6.5 \pm 0.7 \mathrm{MPE}$ in Chicken and $6.6 \pm 0.4$ in Plant, with no differences between interventions (time x treatment $P=0.323$ ).

Mixed muscle protein synthesis rates are shown in Fig. 4. Basal muscle protein synthesis rates did not differ between interventions (Chicken: $0.031 \pm 0.013 \% \mathrm{~h}^{-1}$ and Plant: $\left.0.031 \pm 0.011 \% \mathrm{~h}^{-1}, P=0.884\right)$. Muscle protein synthesis rates increased from the basal to the $0-5 \mathrm{~h}$ postprandial period $\left(0.056 \pm 0.015 \% \mathrm{~h}^{-1}\right.$ in Chicken and $0.046 \pm 0.010 \% \mathrm{~h}^{-1}$ in Plant; main time effect, $P<0.001$; Fig. $4($ a) ) but did not differ 

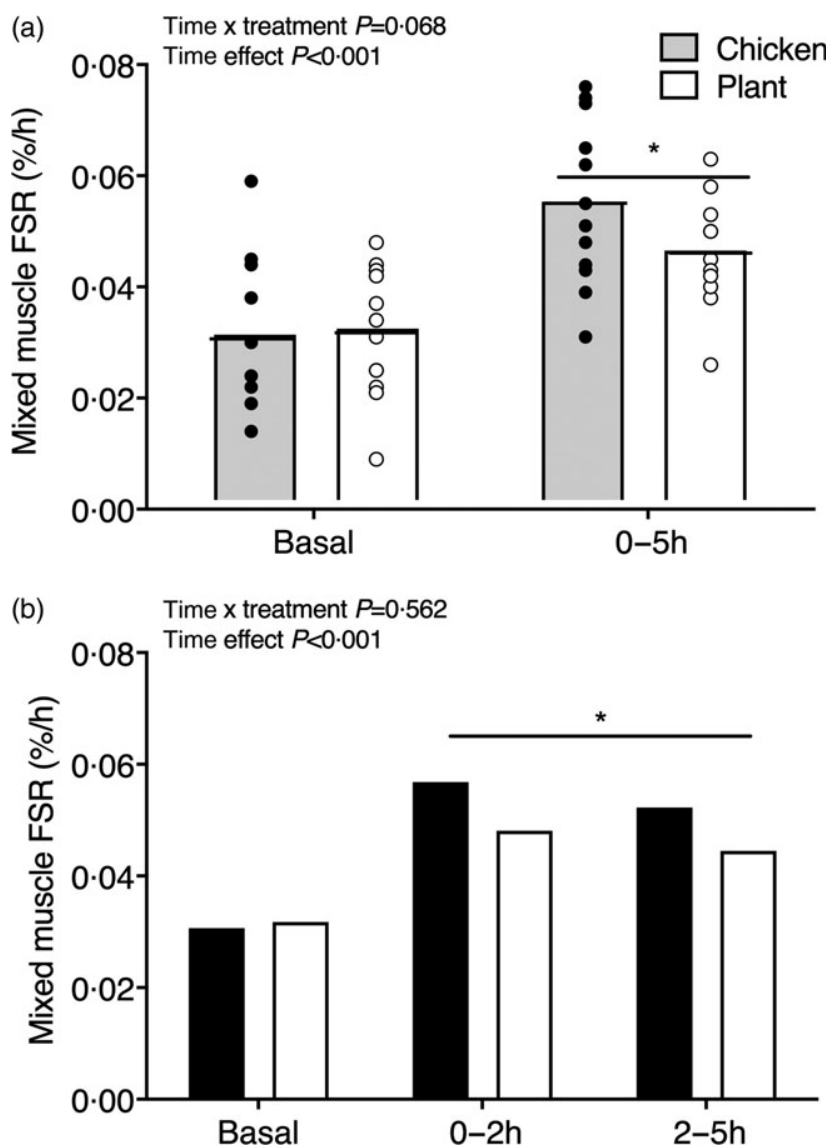

Fig. 4. Mixed muscle protein fractional synthesis rates $\left(\% \cdot \mathrm{h}^{-1}\right)$ during the basa and $0-5 \mathrm{~h}$ postprandial period (a) and the early $(0-2 \mathrm{~h})$ and late $(2-5 \mathrm{~h})$ postprandial period (b), using intravenous $\mathrm{L}-\left(\right.$ ring $-{ }^{13} \mathrm{C}_{6}$ )-phenylalanine infusions in twenty-four healthy, young men following the ingestion of $40 \mathrm{~g}$ of protein of either a lysine-enriched, wheat and chickpea protein product (Plant; $n=12$ ) or chicken breast fillet (Chicken; $n=12$ ). Bars are means and dots represent individual values. Data were analysed with unpaired Student's $t$ test (between treatments) and repeated-measures (time $\times$ treatment) ANOVA. (a) Time $\times$ treatment interaction $P=0.068$; main time effect, $P<0.001$, main treatment effect, $P=0.369$. (b) Basal between treatments, $P=0.884$; time $\times$ treatment interaction, $P=0.562$, main time effect, $P=0.006$, main treatment effect, $P=0.261$. FSR, fractional synthesis rates.

between treatments (time x treatment $P=0.068$, main treatment effect, $P=0.369)$. Similarly, postprandial FSR in the early, $0-2 \mathrm{~h}\left(0.057 \pm 0.021 \% \mathrm{~h}^{-1}\right.$ in Chicken and $0.048 \pm 0.016 \% \mathrm{~h}^{-1}$ in Plant) and late, $2-5 \mathrm{~h}$ postprandial period $\left(0.052 \pm 0.023 \% \mathrm{~h}^{-1}\right.$ in Chicken and $0.044 \pm 0.027 \% \mathrm{~h}^{-1}$ in Plant) increased when compared with basal rates (main time effect, $P<0.001$ ), with no differences between treatments (time x treatment $P=0.562$, main treatment effect $P=0 \cdot 261$; Fig. 4(b)).

\section{Muscle protein signalling}

Key anabolic muscle signalling proteins are shown in Fig. 5. No differences over time or between groups were observed in phosphorylation status of mammalian target of rapamycin $\left(\mathrm{mTOR}^{\mathrm{Ser2448}}\right)$, p70 ribosomal protein S6 kinase (p70S6 $\mathrm{k}^{\mathrm{Thr} 389}$ ), ribosomal protein $\mathrm{S} 6\left(\mathrm{rS}^{\mathrm{Ser} 235 / 236}\right)$ and eukaryotic initiation factor $4 \mathrm{E}$ binding protein- $1\left(4 \mathrm{E}-\mathrm{BP} 1^{\mathrm{Th} 37 / 46}\right)$ at 2 and $5 \mathrm{~h}$ after protein ingestion $(P>0 \cdot 05)$.

\section{Discussion}

In the present study, we compared the muscle protein synthetic response following the ingestion of $40 \mathrm{~g}$ of protein in the form of a lysine-enriched, wheat and chickpea protein-based product with the ingestion of an isonitrogenous amount of chicken in healthy, young men. The ingestion of an ample amount of both the plant-based protein product and an isonitrogenous amount of chicken strongly increased postprandial muscle protein synthesis rates when compared with post-absorptive muscle protein synthesis rates, with no differences observed between the protein sources.

The interest in plant-based products as alternative protein sources is increasing worldwide due to their proposed contribution to better health and greater sustainability ${ }^{(13)}$. However, it is generally reported that plant-based proteins have lesser anabolic properties when compared with animal-based proteins. This has been attributed to the lower EAA contents (leucine in particular) and deficiencies in specific amino acids (lysine and methionine) in various plant-based proteins. The combination of different plant-based protein sources and the fortification with deficient free amino acids have been suggested as effective strategies to increase the anabolic properties of plant-based protein sources. Such plant-based protein food products, aiming to replace meat or poultry, are becoming increasingly popular. However, their capacity to stimulate postprandial muscle protein synthesis has never been investigated. Therefore, in the present study, we assessed postprandial muscle protein synthesis rates following ingestion of an ample, $40 \mathrm{~g}$ amount of protein, provided in the form of $230 \mathrm{~g}$ of baked meat substitute (composed of a lysine-enriched blend of wheat and chickpea protein) or $174 \mathrm{~g}$ of baked chicken breast fillet. The products were matched for the amount of protein ingested and, as such, differed in carbohydrate, fat and total energy content (Plant: 559 $\mathrm{kJ}$ and Chicken: $461 \mathrm{~kJ}$ per serving). To our knowledge, this is the first study to compare postprandial protein handling following ingestion of a whole-food plant-based protein product with an equivalent amount of protein derived from animal-based origin.

Following protein ingestion, greater increases in plasma glucose and insulin concentrations were observed following consumption of the plant-based product when compared with an isonitrogenous amount of chicken (Fig. 1). Plasma EAA and branched-chain amino acid concentrations increased to a greater extent following ingestion of the $40 \mathrm{~g}$ of protein as chicken (Fig. 3), with higher postprandial plasma leucine and methionine concentrations when compared with the ingestion of the plant-based protein source (Fig. 2). To compensate for any potential limiting effect of the low lysine and EAA content of wheat and chickpea protein ${ }^{(15)}$, the plant-based protein product was fortified with free lysine at about $200 \%$ of the recommended levels of the FAO/WHO ((18); Table 3) and as such suitable for consumers as a meat substitute. As a result, postprandial plasma lysine concentrations further increased following the ingestion of Plant when compared with Chicken. No differences between interventions were observed in postprandial non-essential amino acid concentrations or the sum of all amino acids when assessed over the entire 5-h postprandial period (Fig. 3). As such, despite that the products were 


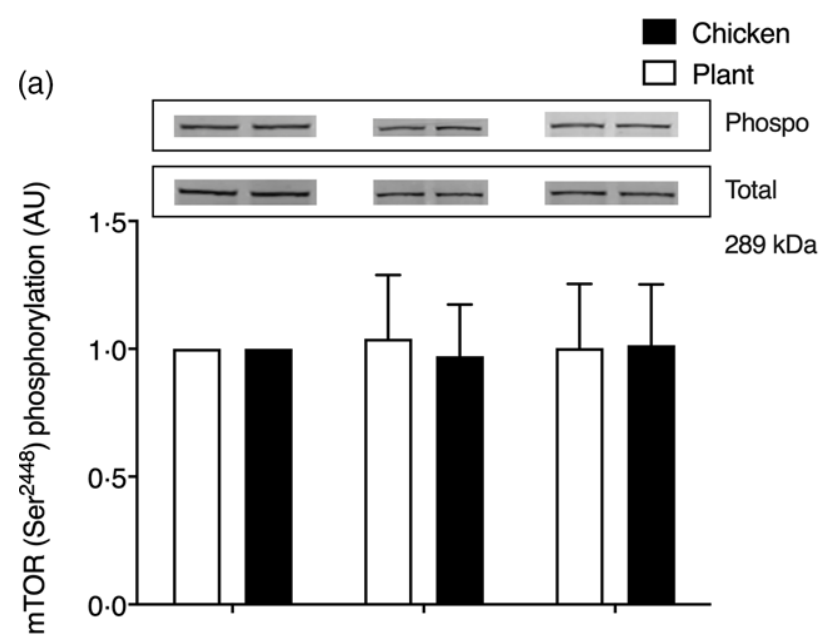

(b)

(c)
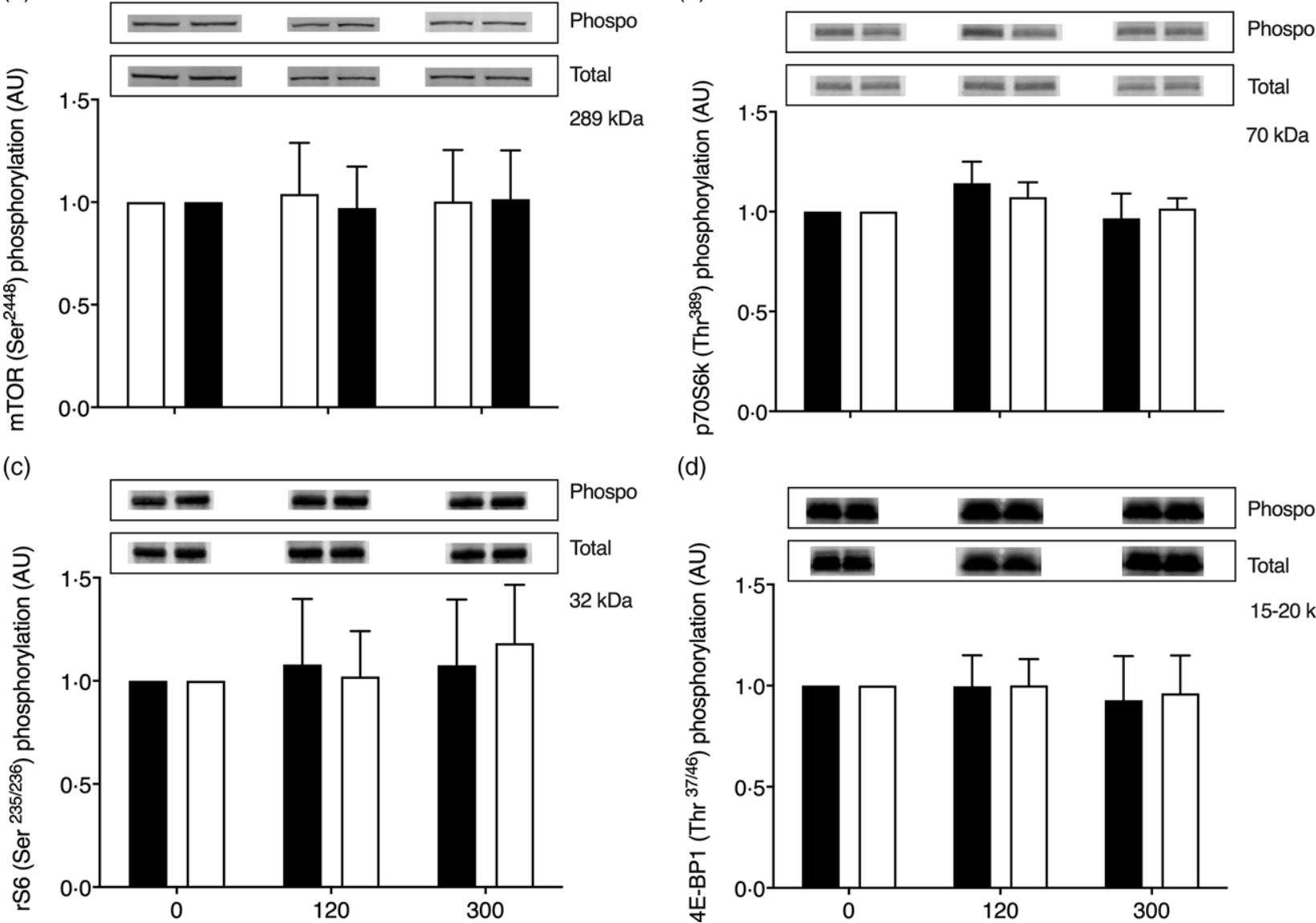

(d)

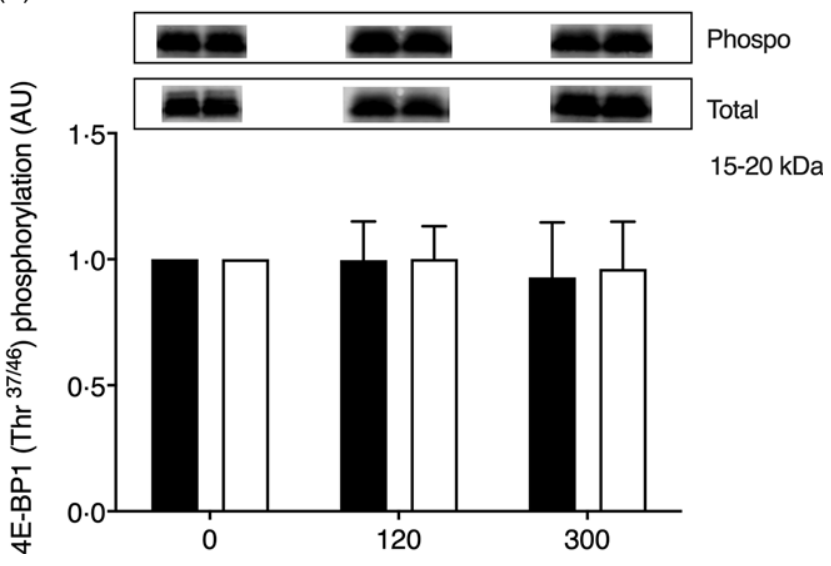

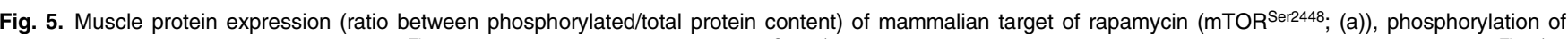
p70 ribosomal protein S6 kinase (p70S6 $\mathrm{k}^{\text {Thr3389; }}$ (b)), ribosomal protein S6 ( $\mathrm{rS6}^{\mathrm{Ser} 235 / 236}$; (c)) and eukaryotic initiation factor 4E binding protein-1 (4E-BP1 $1^{\text {Thr37/46; }}$ (d)) in twenty-four healthy, young men in the post-absorptive state (0) and 120 and $300 \mathrm{~min}$ following the ingestion of $40 \mathrm{~g}$ of protein of either a lysine-enriched, wheat and chickpea protein product (Plant; $n=12$ ) or chicken breast fillet (Chicken; $n=12$ ) with representative blots for phosphorylated and total protein expression of each protein. Values represent means and standard deviation. Data were analysed with unpaired Student's $t$ test (between treatments) and repeated-measures (time $\times$ treatment) ANOVA. No significant main effects were detected. AU, arbitrary units.

protein-matched and had similar EAA contents (about $28 \mathrm{~g} / 100 \mathrm{~g}$, Table 2), the higher energy content and the greater amount of fat and carbohydrate of the plant-based protein product likely attenuated protein digestion and amino acid absorption contributing to the attenuated postprandial rise in plasma amino acid availability when compared with the ingestion of the isonitrogenous amount of baked chicken ${ }^{(10,27-30)}$.

The few studies that assessed the muscle protein synthetic response following plant-based protein ingestion have shown lower postprandial muscle protein synthesis rates when compared with animal-based proteins ${ }^{(6,7,17,18)}$. The lesser anabolic properties of plant-based protein isolates (such as wheat) compared with high-quality animal-based protein sources (such as milk) may be compensated for by ingesting more protein ${ }^{(6)}$. However, simply increasing the protein dose may not always be a feasible and practical strategy to increase the anabolic properties of a plant-based protein meal, since this would further increase both the volume and the energy content of a meal. In the present study, ingestion of $40 \mathrm{~g}$ of protein in the form of the plant-based protein product increased muscle protein synthesis rates by about $68 \%$ when compared with post-absorptive muscle protein synthesis rates (Fig. 4(a); $P<0.001)$. Clearly, a measurable increase in muscle protein synthesis rates can be observed following the consumption of an ample amount of a plant protein-based meat substitute. The selected plant-based meat alternative was produced using a blend of wheat and chickpea protein isolates and further fortified with lysine to achieve levels recommended by the $\mathrm{FAO} / \mathrm{WHO}^{(18)}$; Table 3). Whether the lysine fortification was required to support the postprandial increase in muscle protein synthesis cannot be derived from this study design. More work will be needed to assess whether plant-derived protein blends with or without (free) amino acid fortification are required to allow significant increases in muscle protein synthesis rates following ingestion of more moderate amounts and different compositions of plant-based protein products as well as more complete, mixed meals.

To allow a comparison of the postprandial muscle protein synthetic response to the ingestion of a plant-based meat substitute with a high-quality animal-based protein source, 
we included a control trial in which we provided young individuals with an isonitrogenous amount of chicken. Despite the greater postprandial rise in plasma EAA, and leucine in particular, following the ingestion of chicken, we observed no significant differences in postprandial muscle protein synthesis rates assessed over the $0-5-\mathrm{h}$ between the interventions (Fig 4(a); time $\mathrm{x}$ treatment $P=0.068$, main treatment effect $P=0.369$ ). Though we did observe a trend of a greater overall response in muscle protein synthesis rates in the Chicken treatment, this trend was no longer present when we assessed the postprandial muscle protein synthetic response in the early $(0-2 \mathrm{~h})$ and late $(2-5 \mathrm{~h})$ postprandial phase (Fig. 4(b); time x treatment $P=0.237$ and 0.394 , respectively). In line, we did not detect any substantial differences in myocellular anabolic signalling following ingestion of the plant-based protein product and chicken $(P>0 \cdot 05$, Fig. 5). No detectable rise in phosphorylation status of mTOR, p70S6k, rS6 and 4E-BP1 was observed 2 and $5 \mathrm{~h}$ after protein ingestion in either treatment. These findings may seem inconsistent to the observed substantial postprandial rise in muscle protein synthesis rates. However, it should be noted that signalling responses merely provide snapshot measurements in time and do not necessarily serve as a proxy for the rise in muscle protein synthesis rates. It is likely that transient differences in anabolic signalling occurred prior to the biopsy collection at $2 \mathrm{~h}$ following protein ingestion. Nevertheless, these data clearly show that the ingestion of an ample amount of plant-based meat substitute has the capacity to stimulate muscle protein synthesis to an extent similar to the ingestion of an equivalent amount of animal-based protein source. It is evident that more work will be required to define the factors, such as the amount of protein consumed, that may contribute to the presence or absence of differences in the postprandial muscle protein synthetic response to the ingestion of plant $v$. animal-based protein foods. Relevant factors will likely include the $\operatorname{dose}^{(1,3,6,31)}$, protein source $^{(2,5-7,18)}$, matrix of the food ${ }^{(9-11)}$, food processing ${ }^{(32,33)}$ and preparation of the foods ${ }^{(34-36)}$, as well as the population consuming these products ${ }^{(37)}$.

There is a growing popularity and accessibility of plant-based protein sources, and the consumption of plant-based proteins has increased with campaigns, such as 'Meatless Mondays' and 'flexitarianism' that are advocating a more plant-based $\operatorname{diet}^{(38-40)}$. As a response, the industry has been investing in the development and production of a growing range of plantbased protein food products ${ }^{(13,41)}$. Previous studies that assessed muscle protein synthesis rates following the ingestion of plantbased protein sources have generally been limited to the ingestion of protein isolates derived from soy ${ }^{(5,7,17,18)}$, wheat ${ }^{(6)}$, or blends of casein, whey and soy ${ }^{(21-23)}$ in the form of a liquid protein drink. Moreover, commercially available plant-based protein products are naturally higher in carbohydrate and fat (and consequently energy content) when compared with animal-based protein sources and, therefore, might be less effective in their capacity to stimulate muscle protein synthesis. To date, studies assessing postprandial muscle protein synthesis rates following protein-containing whole-food products or meals are lacking. We $\mathrm{W}^{(42,43)}$ and others ${ }^{(44,45)}$ have defined several dietary factors that can modulate protein digestion and amino acid absorption and the subsequent muscle protein synthetic response to protein ingestion. Such factors include the amount and type of protein, macro- and micronutrient composition of the meal, food density and meal composition, food texture, food matrix, food processing, food preparation and temperature (i.e. heating or cooling), and mastication. While most of these modifications seem to affect protein digestion and amino acid absorption kinetics ${ }^{(10,29,34)}$, their impact on postprandial muscle protein synthesis rates remains to be resolved ${ }^{(10,11,29,34)}$. We matched the meals for protein content and provided an ample amount that would be typically ingested during dinner. Here, we show that when an isonitrogenous amount of plantbased protein is consumed and the deficit of one specific amino acid is replaced, a plant-based meat replacement can be as effective as an animal-based protein source to stimulate muscle protein synthesis in healthy, young adults. Though the long-term effect of plant-based protein consumption on protein metabolism needs to be further explored; plant-based meat substitutes may be applied in a regular diet without compromising the capacity to support muscle mass maintenance in young individuals. Whether the fortification of plant-based meat substitutes with other specific amino acids is required to induce a proper anabolic response and how different plant-based protein blends can be combined to improve the amino acid profile and maximise the anabolic properties of plant-based meat replacers remains questions to be addressed in further studies.

In conclusion, the ingestion of an ample amount of lysineenriched, plant-based protein product increases muscle protein synthesis rates in healthy, young men. The muscle protein synthetic response to the ingestion of an ample amount of protein (i.e. $40 \mathrm{~g}$ ) of such a lysine-enriched, plant-derived protein blend does not differ from the ingestion of an isonitrogenous amount of chicken. Plant-based protein products sold as meat replacers may be as effective as animal-based protein sources to stimulate postprandial muscle protein synthesis rates in healthy, young individuals.

\section{Acknowledgements}

We greatly appreciate the assistance of Ino van der Heijden, Linda Mans, Michelle E.G. Weijzen, Lisanne H.P. Houben and Joey S.J. Smeets in the execution of the experiments. Technical expertise from Hasibe Aydeniz, Stefan H.M. Gorissen, Joy P.B. Goessens, Annemarie P. Gijssen, Henk Schierbeek and Wendy E. Sluijsmans during the sample analyses was greatly appreciated.

Financial support and food items for this research were obtained from Tereos (Marckolsheim, France). The project is organised by and executed under the auspices of TiFN (Wageningen, the Netherlands), a public-private partnership on precompetitive research in food and nutrition. The researchers are responsible for the study design, data collection and analysis, decision to publish, and preparation of the manuscript. The industrial partners within TiFN have contributed to the project through regular discussion and were involved in the study design. The funders had no role in data collection and analysis, decision to publish or preparation of the manuscript. 
I. W. K. K., C. L. B., L. C. P. G. M. dG., L. V. and L. J. C. vL. formulated the research question and designed the study. I. W. K. K., P. J. M. P. and T. S. conducted the experimental trials. J. M. X. vK. and A. H. Z. performed the blood and muscle analyses. I. W. K. K. performed the (statistical) data analysis and data interpretation and wrote the manuscript together with L. V. and L. J. Cv. L. I. W. K. K. and L. J. CV. L. had primary responsibility for final content. All authors read and approved the final content of the manuscript.

C. L. B. is employee of Tereos. L. J. Cv. L. has received research grants, consulting fees, speaking honoraria or a combination of these, from Friesland Campina, Tereos and Nutricia Research. I. W. K. K. and L. V. have received speaking honoraria from Nutricia Research. None of the other authors have disclosed any conflicts of interest.

\section{Supplementary material}

For supplementary material/s referred to in this article, please visit https://doi.org/10.1017/S0007114521004906

\section{References}

1. Witard OC, Jackman SR, Breen L, et al. (2014) Myofibrillar muscle protein synthesis rates subsequent to a meal in response to increasing doses of whey protein at rest and after resistance exercise. Am J Clin Nutr 99, 86-95.

2. Moore DR, Robinson MJ, Fry JL, et al. (2009) Ingested protein dose response of muscle and albumin protein synthesis after resistance exercise in young men. Am J Clin Nutr 89, 161-168.

3. Pennings B, Groen B, de Lange A, et al. (2012) Amino acid absorption and subsequent muscle protein accretion following graded intakes of whey protein in elderly men. Am J Physiol Endocrinol Metab 302, E992-E999.

4. Pennings B, Boirie Y, Senden JM, et al. (2011) Whey protein stimulates postprandial muscle protein accretion more effectively than casein and casein hydrolysate in elderly men. $A m$ J Clin Nutr 93, 997-1005.

5. Tang JE, Moore DR, Kujbida GW, et al. (2009) Ingestion of whey hydrolysate, casein, or soy protein isolate: effects on mixed muscle protein synthesis at rest and following resistance exercise in young men. J Appl Physiol 107, 987-992.

6. Gorissen SH, Horstman AM, Franssen R, et al. (2016) Ingestion of wheat protein increases in vivo muscle protein synthesis rates in healthy older men in a randomized trial. J Nutr $\mathbf{1 4 6}$, 1651-1659.

7. Wilkinson SB, Tarnopolsky MA, MacDonald MJ, et al. (2007) Consumption of fluid skim milk promotes greater muscle protein accretion after resistance exercise than does consumption of an isonitrogenous and isoenergetic soy-protein beverage. Am J Clin Nutr 85, 1031-1040.

8. Burd NA, Yang Y, Moore DR, et al. (2012) Greater stimulation of myofibrillar protein synthesis with ingestion of whey protein isolate $v$. micellar casein at rest and after resistance exercise in elderly men. Br J Nutr 108, 958-962.

9. Churchward-Venne TA, Snijders T, Linkens AM, et al. (2015) Ingestion of casein in a milk matrix modulates dietary protein digestion and absorption kinetics but does not modulate postprandial muscle protein synthesis in older men. J Nutr $\mathbf{1 4 5}$, 1438-1445.

10. Burd NA, Gorissen SH, Van Vliet S, et al. (2015) Differences in postprandial protein handling after beef compared with milk ingestion during post exercise recovery: a randomized controlled trial. Am J Clin Nutr 102, 828-836.

11. van Vliet S, Shy EL, Abou Sawan S, et al. (2017) Consumption of whole eggs promotes greater stimulation of post exercise muscle protein synthesis than consumption of isonitrogenous amounts of egg whites in young men. Am J Clin Nutr 106, 1401-1412.

12. Volpi E, Kobayashi H, Sheffield-Moore M, et al. (2003) Essential amino acids are primarily responsible for the amino acid stimulation of muscle protein anabolism in healthy elderly adults. $\mathrm{Am}$ J Clin Nutr 78, 250-258.

13. Willett W, Rockström J, Loken B, et al. (2019) Food in the anthropocene: the EAT-Lancet Commission on healthy diets from sustainable food systems. Lancet 393, 447-492.

14. van Vliet S, Burd NA \& van Loon LJ (2015) The skeletal muscle anabolic response to plant- versus animal-based protein consumption. J Nutr 145, 1981-1991.

15. Gorissen SHM, Crombag JJ, Senden JM, et al. (2018) Protein content and amino acid composition of commercially available plant-based protein isolates. Amino Acids 50, $1685-1695$.

16. Gorissen SHM \& Witard OC (2018) Characterising the muscle anabolic potential of dairy, meat and plant-based protein sources in older adults. Proc Nutr Soc 77, 20-31.

17. Phillips SM (2012) Nutrient-rich meat proteins in offsetting agerelated muscle loss. Meat Sci $\mathbf{9 2}, 174-178$.

18. Yang Y, Churchward-Venne TA, Burd NA, et al. (2012) Myofibrillar protein synthesis following ingestion of soy protein isolate at rest and after resistance exercise in elderly men. Nutr Metab 9, 57.

19. World Health Organization, FAO \& United Nations University (2007) Protein and Amino Acid Requirements in Human Nutrition: Report of a Joint FAO/WHO/UNU Expert Consultation, in World Health Organization, Technical Report Series no. 935. Geneva: WHO.

20. Young VR \& Pellett PL (1994) Plant proteins in relation to human protein and amino acid nutrition. Am J Clin Nutr 59, 1203S-1212S.

21. Reidy PT, Walker DK, Dickinson JM, et al. (2013) Protein blend ingestion following resistance exercise promotes human muscle protein synthesis. J Nutr 143, 410-416.

22. Borack MS, Reidy PT, Husaini SH, et al. (2016) Soy-dairy protein blend or whey protein isolate ingestion induces similar post exercise muscle mechanistic target of rapamycin complex 1 signaling and protein synthesis responses in older men. J Nutr 146, 2468-2475.

23. Reidy, PT, Walker DK, Dickinson JM, et al. (1985) Soy-dairy protein blend, whey protein ingestion after resistance exercise increases amino acid transport, transporter expression in human skeletal muscle. J Appl Physiol 116, 1353-1364.

24. Kelly TL, Wilson KE \& Heymsfield SB (2009) Dual energy x-ray absorptiometry body composition reference values from NHANES. PLoS One $\mathbf{4}$, e7038.

25. Bergstrom J (1975) Percutaneous needle biopsy of skeletal muscle in physiological and clinical research. Scand J Clin Lab Invest 35, 609-616.

26. Burd NA, Pennings B, Groen BB, et al. (2012) The single biopsy approach is reliable for the measurement of muscle protein synthesis rates in vivo in older men. J Appl Physiol 113, 896-902.

27. Gorissen SH, Burd NA, Hamer HM, et al. (2014) Carbohydrate coingestion delays dietary protein digestion and absorption but does not modulate postprandial muscle protein accretion. J Clin Endocrinol Metab 99, 2250-2258.

28. Gorissen, SHM, Burd NA, Hamer HM, et al. (2017) Co-ingesting milk fat with micellar casein does not affect postprandial 
protein handling in healthy older men. Clin Nutr 36 , 429-437.

29. Kim IY, Shin YA, Schutzler SE, et al. (2018) Quality of meal protein determines anabolic response in older adults. Clin Nutr 37, 2076-2083.

30. Hamer HM, Wall BT, Kiskini A, et al. (2013) Carbohydrate co-ingestion with protein does not further augment postprandial muscle protein accretion in older men. Nutr Metab $10,15$.

31. Yang Y, Breen L, Burd NA, et al. (2012) Resistance exercise enhances myofibrillar protein synthesis with graded intakes of whey protein in older men. Br J Nutr 108, $1780-1788$.

32. Barbe F, Ménard O, Le Gouar Y, et al. (2013) The heat treatment and the gelation are strong determinants of the kinetics of milk proteins digestion and of the peripheral availability of amino acids. Food Chem 136, 1203-1212.

33. Nyakayiru J, van Lieshout GA, Trommelen J, et al. (2019) The glycation level of milk protein strongly modulates post-prandial lysine availability in humans. Br J Nutr 123, 545-552.

34. Pennings B, Groen BB, van Dijk JW, et al. (2013) Minced beef is more rapidly digested and absorbed than beef steak, resulting in greater postprandial protein retention in older men. Am J Clin Nutr 98, 121-128.

35. Bax ML, Aubry L, Ferreira C, et al. (2012) Cooking temperature is a key determinant of in vitro meat protein digestion rate: investigation of underlying mechanisms. J Agric Food Chem 60, 2569-2576.

36. Remond D, Machebeuf M, Yven C, et al. (2007) Postprandial whole-body protein metabolism after a meat meal is influenced by chewing efficiency in elderly subjects. Am J Clin Nutr $\mathbf{8 5}$, 1286-1292.
37. Wall BT, Gorissen SH, Pennings B, et al. (2015) Aging is accompanied by a blunted muscle protein synthetic response to protein ingestion. PLOS ONE 10, e0140903.

38. Rose D, Heller MC \& Roberto CA (2019) Position of the society for nutrition education and behavior: the importance of including environmental sustainability in dietary guidance. J Nutr Educ Behav 51, 3-15.e1.

39. de Boer J, Schosler H \& Aiking H (2017) Towards a reduced meat diet: mindset and motivation of young vegetarians, low, medium and high meat-eaters. Appetite 113, 387-397.

40. Lemken D, Spiller A \& Schulze-Ehlers B (2019) More room for legume - consumer acceptance of meat substitution with classic, processed and meat-resembling legume products. Appetite 143, 104412.

41. Curtain F \& Grafenauer S (2019) Plant-based meat substitutes in the flexitarian age: an audit of products on supermarket shelves. Nutrients 11, 2603.

42. Gorissen SH, Remond D \& van Loon LJ (2015) The muscle protein synthetic response to food ingestion. Meat Sci 109, 96-100.

43. Trommelen J, Betz MW \& van Loon LJC (2019) The muscle protein synthetic response to meal ingestion following resistance-type exercise. Sports Med 49, 185-197.

44. Vliet SV, Beals JW, Martinez IG, et al. (2018) Achieving optimal post-exercise muscle protein remodeling in physically active adults through whole food consumption. Nutrients $\mathbf{1 0}$, 224.

45. Gwin JA, Church DD, Wolfe RR, et al. (2020) Muscle protein synthesis and whole-body protein turnover responses to ingesting essential amino acids, intact protein, and proteincontaining mixed meals with considerations for energy deficit. Nutrients 12, 2457. 